\title{
Endonuclease G: a mitochondrial protein released in apoptosis and involved in caspase-independent DNA degradation
}

G van Loo', P Schotte ${ }^{1}$, M van Gurp ${ }^{1}$, H Demol$^{2}$, B Hoorelbeke ${ }^{2}$, K Gevaert ${ }^{2}$, I Rodriguez ${ }^{3}$, A Ruiz-Carrillo ${ }^{4}$, J Vandekerckhove ${ }^{2}$, W Declercq ${ }^{1}, \mathrm{R}$ Beyaert ${ }^{1}$ and $P$ Vandenabeele ${ }^{*, 1}$

1 Flanders Interuniversity Institute for Biotechnology and Ghent University, Department of Molecular Biology, K.L. Ledeganckstraat 35, B-9000 Ghent, Belgium

2 Flanders Interuniversity Institute for Biotechnology and Ghent University, Department of Medical Protein Research, K.L. Ledeganckstraat 35, B-9000 Ghent, Belgium

3 The Rockefeller University, Laboratory of Vertebrate Neurobiology, New York, USA

${ }^{4}$ Department of Molecular and Cell Biology, C.I.D., C.S.I.C., Biotechnology Reference Center of the Generalitat de Catalunya, Barcelona, Spain

* Corresponding author: K.L. Ledeganckstraat 35, B-9000 Ghent, Belgium. Tel.: 32-9-264-51-31; Fax: 32-9-264-53-48;

E-mail: peter.vandenabeele@rug.ac.be

Received 17.7.01; revised 17.8.01; accepted 17.8.01

Edited by G. Melino

\begin{abstract}
A hallmark of apoptosis is the fragmentation of nuclear DNA. Although this activity involves the caspase-3-dependent DNAse CAD (caspase-activated DNAse), evidence exists that DNA fragmentation can occur independently of caspase activity. Here we report on the ability of truncated Bid (tBid) to induce the release of a DNAse activity from mitochondria. This DNAse activity was identified by mass spectrometry as endonuclease $\mathrm{G}$, an abundant $30 \mathrm{kDa}$ protein released from mitochondria under apoptotic conditions. No tBid-induced endonuclease $G$ release could be observed in mitochondria from Bcl-2-transgenic mice. The in vivo occurrence of endonuclease $\mathrm{G}$ release from mitochondria during apoptosis was confirmed in the liver from mice injected with agonistic anti-Fas antibody and is completely prevented in Bcl-2 transgenic mice. These data indicate that endonuclease $G$ may be involved in CAD-independent DNA fragmentation during cell death pathways in which truncated Bid is generated. Cell Death and Differentiation (2001) 8, 1136-1142.
\end{abstract}

Keywords: apoptosis; caspase; mitochondria; tBid; endonuclease $\mathrm{G}$

Abbreviations: AIF, apoptosis inducing factor; CAD, caspaseactivated DNAse; ICAD, inhibitor of caspase-activated DNAse; MALDI, matrix-assisted laser desorption ionization; MS, mass spectrometry; PSD, post-source decay; tBid, truncated Bid

\section{Introduction}

Internucleosomal DNA fragmentation is a hallmark of the apoptotic process. The best characterized enzyme responsible for this DNA fragmentation is the caspase-activated DNAse CAD (also called DNA fragmentation Factor 40, DFF40) ${ }^{1,2}$ that forms an inactive heterodimer with ICAD, the inhibitor of CAD (also called DFF45). ${ }^{1,3}$ Under apoptotic conditions, ICAD is proteolyzed by caspase- 3 causing the dissociation of the CAD/ICAD heterodimer, releasing CAD, which then translocates from the cytosol to the nucleus. Cells derived from mice that lack ICAD or that express caspaseresistant mutant ICAD have reduced DNA fragmentation, showing that CAD is the major DNAse implicated. ${ }^{3,4}$ However, the development of these mice appeared to be normal, suggesting that CAD activity is not required for mammalian developmental cell death. ${ }^{4,5}$

Apoptosis Inducing Factor (AIF), ${ }^{6}$ a mitochondrial flavoprotein translocated to the nucleus during the process of apoptosis is implicated in large scale $(\sim 50 \mathrm{~kb})$ DNA fragmentation and peripheral chromatin condensation, but not oligonucleosomal DNA laddering. ${ }^{7}$ Acinus, a chromatin condensation factor, was shown to induce nuclear pyknosis in the absence of DNAse activity. ${ }^{8}$ Although no clear in vivo relevance has been provided yet, other factors being involved in nuclear DNA fragmentation during the apoptotic process have been described. .,10 $^{2}$

In our search for proteins that are released from mitochondria after an apoptotic stimulus, we identified endonuclease $\mathrm{G}$ as such a candidate, using an in vitro reconstitution system with purified recombinant tBid or apoptotic cytosol from Fas-treated L929sAhFas cells on isolated mitochondria. Endonuclease G, a mitochondrial nuclease that has been suggested to play a role in mitochondrial DNA replication, ${ }^{11}$ was clearly released together with cytochrome $c$. When incubated with purified nuclei, the tBid-induced mitochondrial supernatant could evoke DNA degradation. This activity was absent in supernatant of tBid-treated mitochondria from Bcl-2 transgenic mice and could not be prevented by caspaseinhibitors. The release of endonuclease $\mathrm{G}$ during apoptosis was confirmed in vivo in a model of anti-Fas induced fulminant hepatitis.

\section{Results}

\section{tBid-induced release of mitochondrial proteins}

To study the release of mitochondrial proteins by tBid during the process of apoptosis we generated recombinant murine tBid. Incubation of recombinant $t B i d$ with isolated murine liver mitochondria induced the release of cytochrome $c$ (Figure 
A.

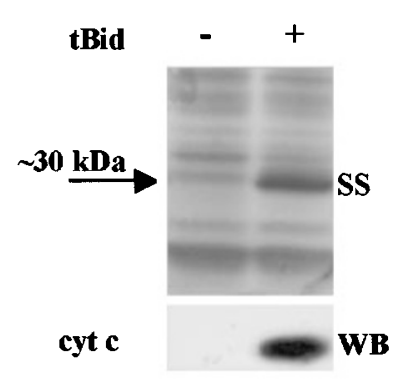

B.

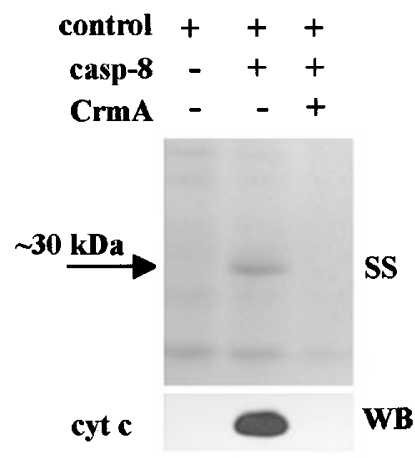

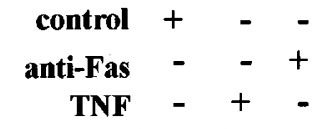

TNF -+

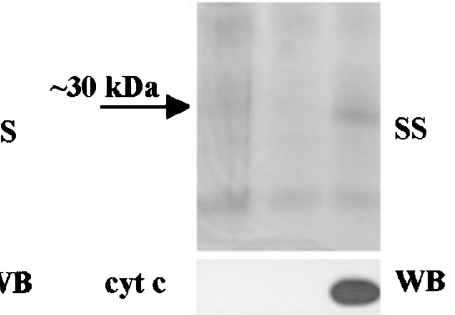

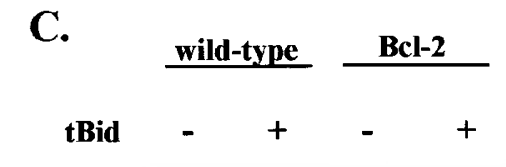
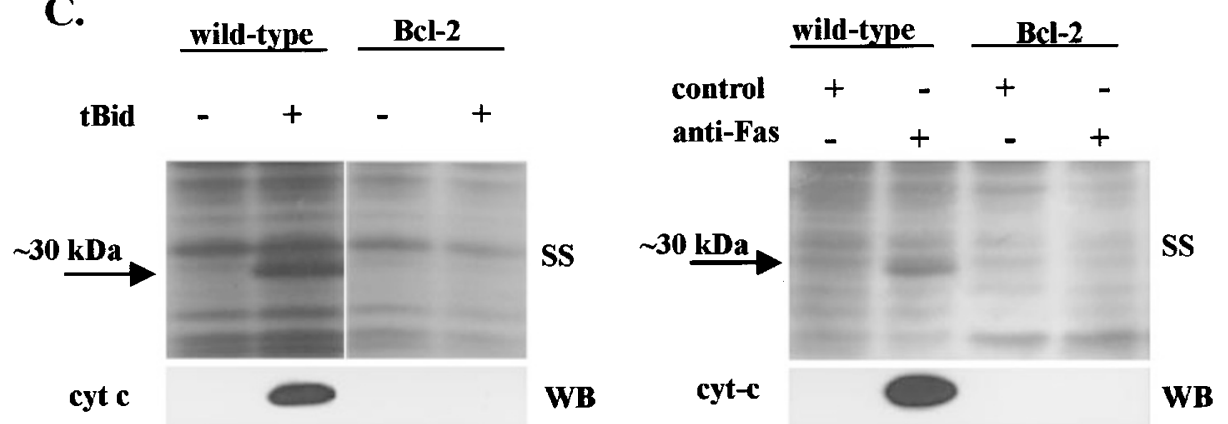

Figure 1 Modulation of the release of a $\sim 30 \mathrm{kDa}$ protein in isolated mitochondria. $(\mathbf{A})$ tBid-induced release of cytochrome $c$ and a $\sim 30 \mathrm{kDa}$ protein. Mouse liver mitochondria were incubated with control buffer or $10 \mathrm{ng}$ (corresponding to $6.7 \mathrm{nM}$ ) recombinant tBid. Supernatants were separated by means of $15 \%$ SDS - PAGE followed by Western Blotting (WB) using an anti-cytochrome $c$ antibody or by silver staining (SS). (B) Induction of cytochrome $c$ and the $\sim 30 \mathrm{kDa}$ protein release by apoptotic L929sAhFas cytosol. Non-treated L929sAhFas control cytosol was preincubated with recombinant murine caspase-8 $(1 \mu \mathrm{g})$ and recombinant CrmA ( $\mu \mathrm{g})$ as indicated, and incubated with liver mitochondria (left panel). Non-treated L929sAhFas control cytosol, anti-Fas antibody-induced (250 ng/ml) L929sAhFas apoptotic cytosol and mTNF-induced $(10000 \mathrm{U} / \mathrm{ml})$ L929sAhFas necrotic cytosol were incubated with liver mitochondria as indicated (right panel). The supernatants were recovered after centrifugation and immunoblotted with an anti-cytochrome $c$ antibody (WB) or visualized by silver staining (SS). (C) Inhibition of tBid- and L929sAhFas cytosol-induced release of cytochrome $c$ and $\sim 30 \mathrm{kDa}$ protein by Bcl-2. Recombinant tBid (10 ng) was incubated with liver mitochondria from wild-type or liver-specific Bcl-2 transgenic mice (left panel). Non-treated L929sAhFas control cytosol and anti-Fas antibody-induced (250 ng/ml) L929sAhFas apoptotic cytosol were incubated with liver mitochondria as indicated (right panel). The supernatants were recovered after centrifugation and immunoblotted with an anti-cytochrome $c$ antibody (WB) or visualized by silver staining (SS)

1A). In parallel, a silver staining profile of the mitochondrial supernatant revealed the presence of a $\sim 30 \mathrm{kDa}$ protein as compared to untreated control supernatant. As endogenous Bid is cleaved under apoptotic conditions, we prepared cytosol from L929sAhFas cells and treated that with recombinant caspase-8. When incubated with purified mitochondria, this activated cytosol was able to induce the release of cytochrome $c$ and the $\sim 30 \mathrm{kDa}$ protein, a process that was blocked in the presence of recombinant CrmA, a caspase-8 inhibitor (Figure. 1B, left panel). Neither untreated cytosol nor recombinant caspase alone was able to induce release of cytochrome $c$ or the $\sim 30 \mathrm{kDa}$ protein (Figure 1B and data not shown). A similar observation was done using apoptotic cytosol from anti-Fas treated L929sAhFas cells (Figure 1B, right panel). Immunodepletion of Bid and tBid from the apoptotic cytosol abolished the capacity of the apoptotic cytosol to induce the release of cytochrome $c$ and the $\sim 30 \mathrm{kDa}$ protein (data not shown and see Figure 3B), demonstrating that tBid is required. Under necrotic conditions however, using cytosol from TNF-treated L929sAhFas cells, no release of cytochrome $c$ nor of the $\sim 30 \mathrm{kDa}$ protein could be observed (Figure 1B, right panel).

\section{Inhibition of the $\sim \mathbf{3 0} \mathrm{kDa}$ protein release by $\mathrm{Bcl}-\mathbf{2}$}

To assess the question if $\mathrm{Bcl}-2$ is able to prevent mitochondrial release of the $\sim 30 \mathrm{kDa}$ factor, we prepared liver mitochondria from wild-type and liver-specific Bcl-2 transgenic mice. ${ }^{12}$ As expected, Bcl-2 blocked the release of cytochrome $c$ induced by recombinant tBid (Figure 1C, left panel) and by apoptotic L929sAhFas cytosol (Figure 1C, right panel). Also the release of the $\sim 30 \mathrm{kDa}$ protein was abolished under these conditions as is appreciated from the silver staining profiles.

\section{Mass spectrometric identification of the $\sim 30 \mathrm{kDa}$ factor as endonuclease $\mathbf{G}$}

In order to identify the $\sim 30 \mathrm{kDa}$ factor, a mitochondrial preparation from one mouse liver was exposed to $170 \mathrm{nM}$ purified tBid and the mitochondrial supernatant was separated by means of $15 \%$ SDS - PAGE together with the supernatant of an untreated control, followed by Coomassie Brilliant Blue staining (Figure $2 \mathrm{~A}$ ). The $\sim 30 \mathrm{kDa}$ protein band, present in the tBid-induced supernatant, together with the corresponding 
A.
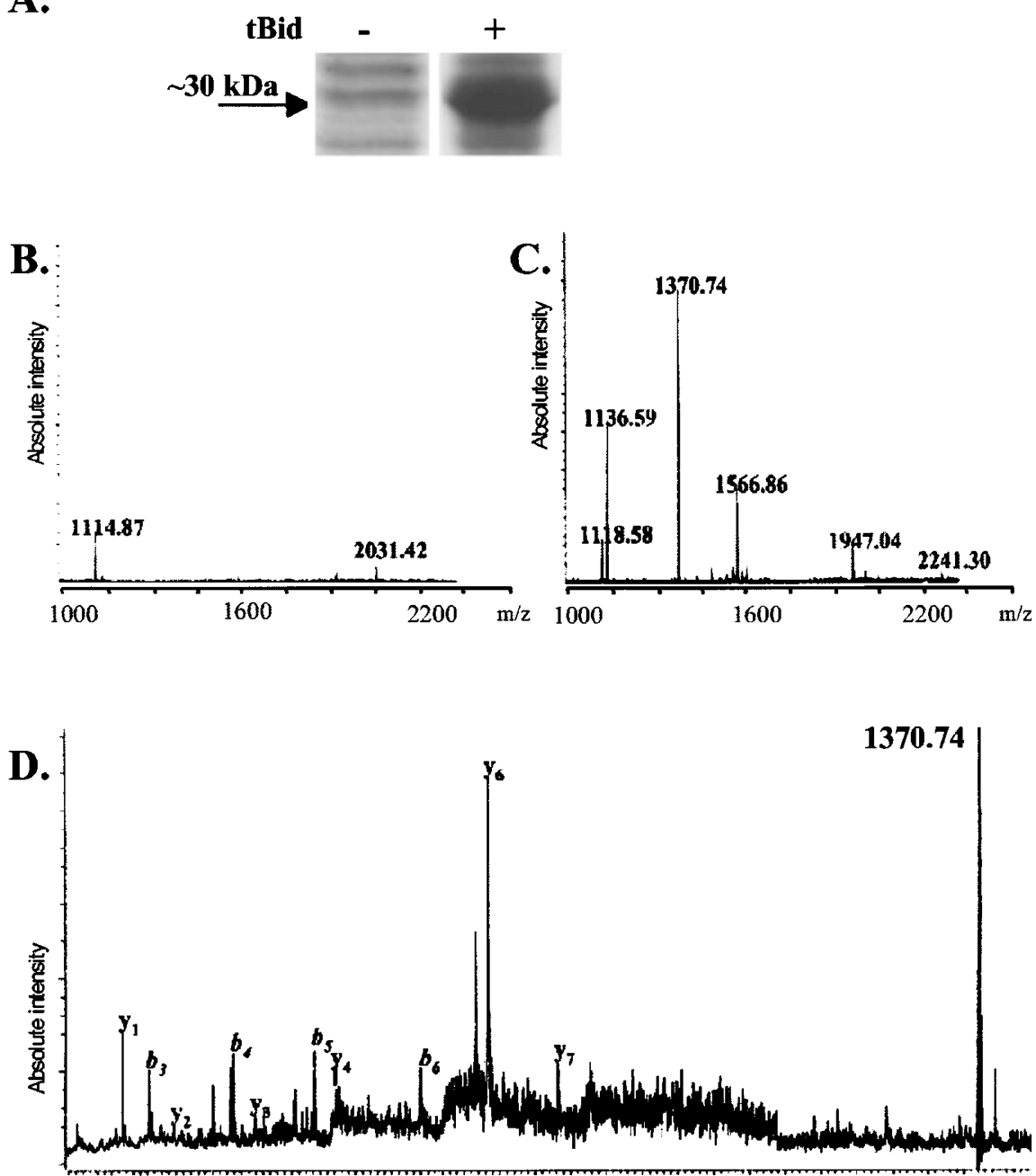

Figure 2 MALDI-MS identification of tBid-induced mitochondrial release of mouse endonuclease G. (A) A mitochondrial preparation of one liver was subjected to $15 \%$ SDS-PAGE and stained with Coomassie Brilliant Blue. (B, C) The $\sim 30 \mathrm{kDa}$ protein band released by tBid and its control were digested using trypsin. The generated peptide mixture was separated by reverse phase-HPLC and shown are MALDI-MS spectra of peptides present in the HPLC-fraction from protein digests in the negative control (B) and tBid-released (C) proteins. (D) MALDI-PSD analysis of the peptide with a mass of 1370.74 Da present in the spectrum of B, led to the identification of the peptide baring the sequence $\mathrm{NH}_{2}$-ASGLLFVPNILAR-COOH of the mouse endonuclease $\mathrm{G}$ protein

region of the lane loaded with control supernatant, were excised from the gel, trypsinized and used for MALDI-MS peptide mass fingerprint analysis. ${ }^{13}$ MALDI-PSD analysis of a peptide with a mass of $1370.74 \mathrm{Da}$, present in the spectrum of the tBid-induced condition but absent in the negative control (Figure 2B and $\mathrm{C}$ ), led to the identification of the peptide baring the sequence $\mathrm{NH}_{2}$-ASGLLFVPNILAR-COOH from the mouse endonuclease $\mathrm{G}$ protein. This was further verified by manually checking the PSD-spectrum for the presence of other tryptic peptide fragments of endonuclease $G$ (Figure 2D). Finally, we identified more fragments that cumulatively covered about $30 \%$ of the amino acid sequence of endonuclease $\mathrm{G}$ (data not shown). The identification was confirmed by Western blotting, demonstrating the clear tBidinduced release of the mitochondrial $30 \mathrm{kDa}$ endonuclease $\mathrm{G}$ together with cytochrome $c$ (Figure 3A). Immunodepletion of endogenous Bid from apoptotic cytosol completely blocked the capacity of apoptotic cytosol to induce the release of endonuclease G (Figure 3B) indicating that Bid is sufficient and essential for mitochondrial endonuclease $G$ release.

\section{Endonuclease G allows caspase-independent nuclear DNA degradation during apoptosis}

Endonuclease $G$ is a mitochondrial nuclease that has been suggested to play a role in mitochondrial DNA replication ${ }^{11}$ but a role in nuclear DNA fragmentation or an involvement in the apoptotic process was never shown, until recently. ${ }^{14,15}$ As endonuclease $\mathrm{G}$ was identified in the mitochondrial supernatant that is released under apoptotic conditions, we investigated the hypothesis that the tBid-induced mitochondrial supernatant possessed intrinsic DNAse activity on isolated nuclei as compared to control supernatant. U937 nuclei were isolated and incubated with supernatant of untreated or tBid-treated mitochondria. As shown in Figure $4 \mathrm{~A}$, tBid-induced mitochondrial supernatant is able to induce 
A.
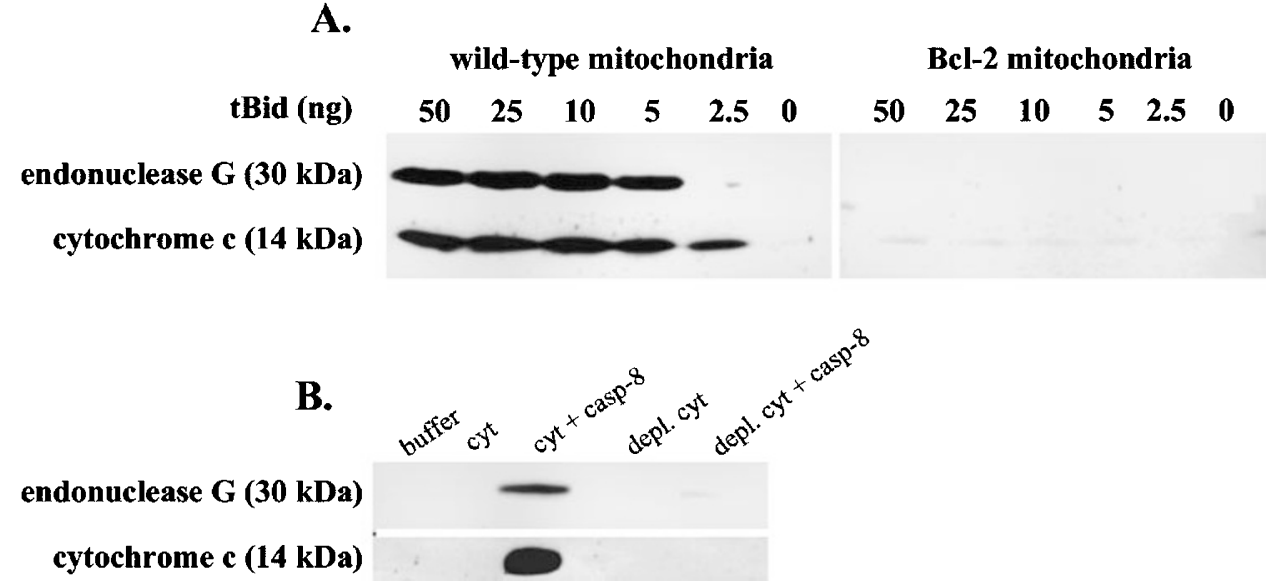

Figure 3 tBid is sufficient and required for mitochondrial endonuclease $\mathrm{G}$ release. (A) tBid was incubated with purified liver mitochondria from wild-type and Bcl-2 transgenic mice. Supernatants were separated from the mitochondrial pellets by centrifugation and subjected to $15 \%$ SDS-PAGE, followed by immunoblotting with anti-endonuclease $G$ and anti-cytochrome $c$ antibody. (B) Endogeneous Bid was immunodepleted from L929sAhFas cytosol (cyt) activated with recombinant caspase-8 $(1 \mu \mathrm{g})$ prior to incubation with mitochondria, as indicated. Supernatants were isolated and subjected to SDS-PAGE followed by immunoblotting with antiendonuclease $\mathrm{G}$ or anti-cytochrome $c$

A.

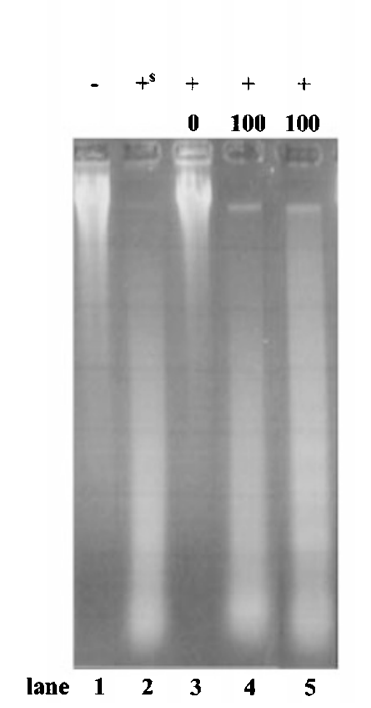

B.

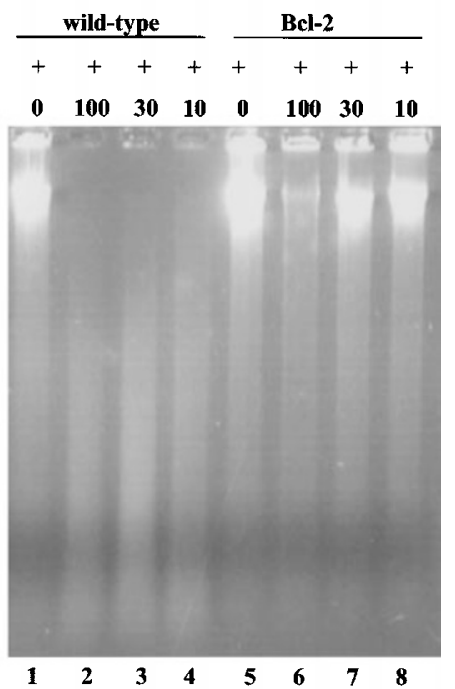

Figure 4 tBid mitochondrial supernatant induces DNA fragmentation on isolated U937 nuclei, an activity that is absent in Bcl-2 mitochondrial supernatant. (A) U937 nuclei were incubated with supernatant of wild-type mitochondria induced with 0 or $100 \mathrm{ng}$ tBid (lanes 3 and $4-5$ respectively) in the absence (lane 1-4) or presence of DEVD-fmk inhibitor (lane 5). As controls, U937 nuclei were incubated with buffer alone (lane 1) and sonicated mitochondria (lane 2). (B) U937 nuclei were incubated with supernatant of wild type mitochondria (lanes $1-4$ ) or $\mathrm{Bcl}-2$ transgenic mitochondria (lane 5-8) induced with $0,100,30$, and $10 \mathrm{ng}$ tBid respectively. All samples (A and $\mathbf{B}$ ) were analyzed by means of agarose gel electrophoresis and detection of DNA with ethidium bromide staining

DNA fragmentation while control supernatant is not. In Bcl-2 mitochondria no DNAse activity is released when exposed to tBid (Figure 4B). This observation is in accordance with the fact that endonuclease $G$ release is prevented in mitochondria from Bcl-2 transgenic mice (Figure 1C). Western blotting revealed no caspase immunoreactivity in the supernatant of the mitochondria (caspases-1, $-2,-3,-6,-7,-8,-9,-11$; data

not shown). In line with that, no DEVDase activity was detectable in tBid-induced mitochondrial supernatant (data not shown) nor could the caspase-3 specific inhibitor DEVDfmk block the DNA fragmentation generated by tBid-induced mitochondrial supernatant (Figure 4A). These data clearly show that the nuclease activity on isolated nuclei acts independent of caspase activity and is different from the caspase-3 dependent nuclease activity of CAD.

To verify the in vivo relevance of the release of endonuclease $\mathrm{G}$ during the apoptotic process, C57BL/6 wild-type and $\mathrm{Bcl}-2$ transgenic mice ${ }^{12}$ were injected with agonistic anti-Fas antibody. While Bcl-2 transgenic mice were very well protected against a lethal dose of anti-Fas antibody, wild-type mice died of massive liver apoptosis (data not shown). As shown in Figure 5, release of endonuclease $\mathrm{G}$ from mitochondria to cytosol, together with cytochrome $c$, can be demonstrated in anti-Fasinjected wild-type mice, in contrast to $\mathrm{Bcl}-2$ littermates.

These data indicate that endonuclease $\mathrm{G}$ also in vivo is released during the apoptotic process and may participate in DNA degradation.

\section{Discussion}

In our search for proteins that are released from mitochondria during the process of apoptosis, we used an in vitro reconstitution system in which isolated mitochondria were treated with purified recombinant $\mathrm{tBid}$ or endogeneous $\mathrm{tBid}$ using apoptotic cytosol from anti-Fas antibody treated L929sAhFas cells (Van Loo et al., submitted). One of the proteins we identified by mass spectrometric analysis of the mitochondrial supernatant was endonuclease G. Endogenous levels of Bid are sufficient and essential for endonuclease $G$ release from mitochondria as immunodepletion of Bid from cytosol incubated with mitochondria in vitro completely abrogated the release of the protein. Apoptotic release of mitochondrial endonuclease $\mathrm{G}$ was completely blocked in conditions where $\mathrm{Bcl}-2$ was overexpressed. Under necrotic 


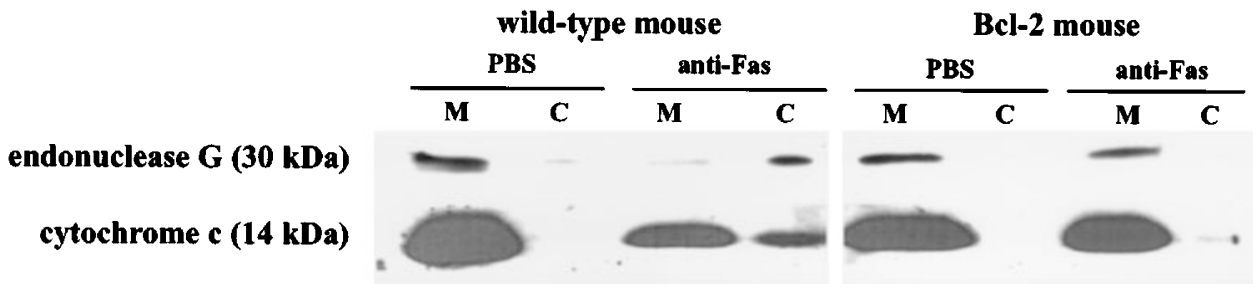

Figure 5 Endonuclease $\mathrm{G}$ is released from mitochondria of apoptotic cells during in vivo apoptosis. Wild type and Bcl-2 transgenic mice were intravenally injected with PBS or agonistic anti-Fas antibody and liver mitochondria were prepared as described in Materials and Methods. One hundred $\mu \mathrm{g}$ of mitochondrial (M) and cytosolic (C) lysates were subjected to $15 \%$ SDS-PAGE, followed by immunoblotting with anti-endonuclease G or anti-cytochrome $c$ antibody

conditions, endonuclease $\mathrm{G}$ seems not to be released from mitochondria as was shown with necrotic L929sAhFas cytosol reconstituted with purified mitochondria in vitro.

Endonuclease $\mathrm{G}$ is a mitochondrial nuclease that is likely implicated in mitochondrial DNA replication. ${ }^{11}$ and is synthesized as a propeptide with an amino-terminal presequence that targets the nuclease to mitochondria. ${ }^{11}$ Besides these data, little is known about the precise function of endonuclease $G$ but it was never associated with nuclear DNA fragmentation or cell death in general. Although endonuclease $\mathrm{G}$ implication in mitochondrial DNA replication favors the idea of a matrix localization, the released mitochondrial fraction of endonuclease $\mathrm{G}$ is rather confined to the intermembrane space as we could clearly show that the matrix protein adenylate kinase 3 was retained within the mitochondria after exposure to tBid (data not shown; Van Loo et al., submitted).

As we identified endonuclease $G$ as one of the proteins that is clearly released from mitochondria by an apoptotic trigger, we addressed the question if this nuclease could be involved in apoptotic nuclear DNA fragmentation. Our experiments revealed that the mitochondrial supernatant that was released under apoptotic conditions with tBid could clearly induce DNA fragmentation when incubated with isolated nuclei. This activity was absent in tBid-induced mitochondrial supernatant from Bcl-2 transgenic mice. Moreover, neither procaspases or activated caspases were detectable by Western blotting or by an enzymatic assay, nor did the addition of caspase-inhibitors affect nuclear DNA degradation, demonstrating a caspase-independent action of this DNAse activity. The in vitro data obtained with isolated mitochondria could be confirmed in vivo in a murine model of lethal hepatitis. Administration of agonistic anti-Fas antibodies induced the release of both endonuclease $\mathrm{G}$ and cytochrome $c$ from the mitochondria to the cytosol. This mitochondrial release was completely absent in $\mathrm{Bcl}-2$ transgenic mice. Since CAD and ICAD are very low expressed in liver tissue $\left({ }^{5,16}\right.$ and $S$ Nagata, personal communication), the clear DNA fragmentation observed in this tissue during fulminant hepatitis may be mediated by mitochondrial endonuclease $G$ release. However, the actual contribution of this nuclease in apoptotic DNA fragmentation remains to be determined.

These data open an interesting possibility of defining a caspase-independent cell death pathway leading to DNA fragmentation. Many different apoptogenic stimuli impinge on the specific proteolysis of Bid. Proteolysis of Bid is exerted by caspases to generate $15 \mathrm{kDa}$ tBid, ${ }^{17,18}$ by granzyme $\mathrm{B}$ to generate $14 \mathrm{kDa} \mathrm{gtBid}^{19}$ or by lysosomal proteases. ${ }^{20}$ The latter two proteolytic cascades may allow the release of endonuclease $G$ independent of active caspases resulting in caspase-independent DNA degradation. A DNAse that can act independently of caspases may still allow DNA fragmentation in the presence of exogenous or endogenous caspase inhibitors. ${ }^{21}$ This caspase-independent DNA fragmentation also impairs the definition of apoptosis as a caspase-dependent phenomenon. ${ }^{21}$

Recently, Li et al. ${ }^{15}$ encountered the same caspaseindependent nuclease pathway initiated from mitochondria. The residual nucleosomal DNA fragmentation observed in ICAD transgenic mice and in caspase-resistant ICAD mice, ${ }^{4,5}$ could be due to endonuclease $G$, as the release and translocation of endonuclease $\mathrm{G}$ from mitochondria to the nucleus in ICAD-deficient embryonic fibroblasts has been observed. In another study, using a functional genetic screen, the nuclease $\operatorname{csp}-6$ was identified as the first mitochondrial protein involved in programmed cell death in C. elegans. Csp6 is most probably the nematode counterpart of endonuclease $\mathrm{G}^{14}$ providing evidence for an evolutionarily conserved link between the mitochondria and nuclear apoptosis.

To conclude, these data suggest that the tBid-induced release of endonuclease $\mathrm{G}$ may be involved in CADindependent DNA fragmentation. Under these conditions caspase-3 would not be required for nuclear DNA degradation.

\section{Materials and Methods}

\section{Reagents}

Monoclonal hamster anti-mouse Fas antibody Jo2 (Pharmingen, San Diego, CA, USA) was dissolved in endotoxin-free PBS and injected intravenally $(15 \mu \mathrm{g} / 200 \mu \mathrm{l}$ per mouse). Livers were excised from sacrificed mice and placed into ice-cold homogenization buffer $(5 \mathrm{mM}$ $\mathrm{KH}_{2} \mathrm{PO}_{4} \mathrm{Ph} 7.4,0.3 \mathrm{M}$ sucrose, $1 \mathrm{mM}$ EGTA, $5 \mathrm{mM}$ MOPS). The caspase peptide inhibitor acetyl-Asp-Glu-Val-Asp-fluoromethylketone (Ac-DEVD-fmk) was obtained from Enzyme Systems Products (Dublin, CA, USA), and the caspase fluorogenic substrate acetylAsp-Glu-Val-Asp-aminomethylcoumarin (Ac-DEVD-amc) was obtained from Peptide Institute Inc. (Osaka, Japan).

\section{Expression and purification of recombinant proteins}

Murine tBID (residues 60-195) with a tag of six histidines at the Nterminus was cloned in the pLT10 vector and expressed in Escherichia coli. The protein was recovered in the soluble bacterial fraction and 
purified by cobalt-immobilized metal affinity chromatography (TALON, Clontech, Palo Alto, CA, USA) using the manufacturer's protocol. Active recombinant murine caspase- 8 was expressed and purified by a similar method. ${ }^{22}$ Recombinant cowpox CrmA protein was a generous gift from Dr. G Salvesen (Burnham Institute, La Jolla, CA, USA).

\section{Isolation of murine liver mitochondria}

Livers of $\mathrm{C} 57 \mathrm{BL} / 6$ wild-type and bcl-2 transgenic mice ${ }^{12}$ were homogenized using a Wheaton type $B$ douncer in homogenization buffer ( $5 \mathrm{mM} \mathrm{KH}_{2} \mathrm{PO}_{4} \mathrm{Ph} 7.4,0.3 \mathrm{M}$ sucrose, $1 \mathrm{mM} \mathrm{EGTA}, 5 \mathrm{mM} 3-(\mathrm{N}$ morpholino)propanesulfonic acid). The homogenates were cleared by centrifugation at $1800 \times g$ for $10 \mathrm{~min}$ at $4^{\circ} \mathrm{C}$ to remove intact cells and nuclei. The supernatant was spun down at $10000 \times \mathrm{g}$ for $10 \mathrm{~min}$ at $4{ }^{\circ} \mathrm{C}$ to precipitate the mitochondria containing heavy membrane fraction and further purified on a Percoll gradient as described earlier. ${ }^{23}$ The mitochondrial pellet was resuspended in cell free system (CFS) buffer (10 mM HEPES- $\mathrm{NaOH}$ pH 7.4, $220 \mathrm{mM}$ mannitol, $68 \mathrm{mM}$ sucrose, $2 \mathrm{mM} \mathrm{NaCl}, 2.5 \mathrm{mM} \mathrm{KH}_{2} \mathrm{PO}_{4}, 0.5 \mathrm{mM}$ EGTA, $2 \mathrm{mM} \mathrm{MgCl} 25 \mathrm{mM}$ pyruvate, $0.1 \mathrm{mM}$ PMSF, $1 \mathrm{mM}$ dithiothreitol), kept on ice and used within $1 \mathrm{~h}$ of preparation.

\section{Western Blot analysis of tBID induced release of mitochondrial proteins}

Intact mouse liver mitochondria equivalent of $40 \mu \mathrm{g}$ protein were incubated at $37^{\circ} \mathrm{C}$ in $100 \mu \mathrm{l} \mathrm{CFS}$ buffer for $20 \mathrm{~min}$ with various reagents as indicated in the figure legends. The supernatants were separated from the mitochondria by centrifugation at $20000 \times g$ for $10 \mathrm{~min}$ at $4{ }^{\circ} \mathrm{C}$. One fifth of the supernatant was subjected to $15 \%$ SDS-PAGE followed by Western Blotting with anti-cytochrome $c$ antibody (clone $7 \mathrm{H} 8.2 \mathrm{C} 12$, Pharmingen, CA, USA) or anti-endonuclease $G$ antibody which was made against the peptide AMDDTFYLSN. Blots were visualized with the chemiluminescence NEN Renaissance method (Du Pont, Wilmington, DE, USA) after incubation of membranes with secondary antibody coupled to horseradish peroxidase.

\section{Preparation of L929sAhFas lysates}

L929sAhFas cells were cultured in Dulbecco's Modified Eagle Medium (DMEM), supplemented with penicillin $(100 \mathrm{U} / \mathrm{ml})$, streptomycin $(0.1 \mathrm{mg} / \mathrm{ml})$, L-glutamine $(0.03 \%)$ and fetal calf serum $(10 \%)$. Cells were left untreated, stimulated with $250 \mathrm{ng} / \mathrm{ml}$ agonistic anti-human Fas antibody (clone 2R2, Cell Diagnostica, Müenster, Germany) for $30 \mathrm{~min}$ to $2 \mathrm{~h}$ or with $10000 \mathrm{U} / \mathrm{ml}$ recombinant murine TNF (produced in our laboratory by Alex Raeymaeckers) for $2-7 \mathrm{~h}$. Cells were washed in cold PBS and permeabilized in $0.02 \%$ digitonin (Boehringer Mannheim GmbH, Mannheim, Germany) dissolved in CFS buffer and left on ice for $1 \mathrm{~min}$. This treatment allows selective lysis of the outer cell membrane without affecting the organelle membranes. Lysates were cleared by centrifugation at $20000 \times g$ for $10 \mathrm{~min}$ and stored at $4^{\circ} \mathrm{C}$. For Bid depletion experiments, the digitonin lysate of L929sAhFas cells was precleared three times by incubation for 5 min with $20 \%$ protein $G$ beads (Amersham Pharmacia Biotech, Rainham, UK) and incubated with anti-Bid antibody $\left(10 \mu \mathrm{g} / 5 \times 10^{6}\right.$ cells) (RD Systems Inc., Minneapolis, MN, USA) and the mixture is rocked in the cold for $1.5 \mathrm{~h}$ at $4^{\circ} \mathrm{C}$. The antibody complexes were captured with protein $\mathrm{G}$ beads $(20 \%)$ for $30 \mathrm{~min}$ at $4{ }^{\circ} \mathrm{C}$ and removed by centrifugation. The incubation with anti-Bid antibody was repeated. The resulting Bid-depleted supernatant was used in the reconstitution experiment with purified liver mitochondria.

\section{Protein identification using MALDI-MS}

For purification purposes, a mitochondrial preparation from one liver (corresponding to approximately $1 \mathrm{mg}$ total protein) was incubated with $170 \mathrm{nM}$ purified tBid for $20 \mathrm{~min}$ at $37^{\circ} \mathrm{C}(500 \mathrm{ng} \mathrm{tBid} / 200 \mu \mathrm{l}$ of mitochondria equivalent to $1 \mathrm{mg}$ of total protein). Supernatant was removed from the mitochondria by centrifugation at $20000 \times g$ for $10 \mathrm{~min}$ at $4^{\circ} \mathrm{C}$. Proteins were separated by $15 \%$ SDS - PAGE followed by Coomassie Brilliant Blue staining. The $\sim 30 \mathrm{kDa}$ protein band in the tBid-induced mitochondrial supernatant and the corresponding bands at the same height in the supernatant of unstimulated mitochondria, were excised and in gel digested using trypsin, as described previously. ${ }^{26}$ Following digestion, the supernatant containing the tryptic peptides was removed from the gel pieces and acidified using $1 \mu \mathrm{l}$ of formic acid. A small fraction (10\%) of this mixture was concentrated on Poros 50 R2 beads (Roche Molecular Biochemicals, Basel, Switzerland) and used for MALDI-MS peptide mass-fingerprint analysis, as described previously. ${ }^{13}$ Since the excised gel bands contained multiple proteins, no unambiguous protein identification could be made by solely using the obtained tryptic peptide mass maps. Therefore the remainder of the peptide mixture was loaded on a $1 \mathrm{~mm}$ i.d. $\times 50 \mathrm{~mm}$ Vydac C18-column (Vydac Separations Group, Hesperia, CA, USA) and the peptides were separated by reverse phase-HPLC using an acetonitrile gradient. Eluting peptides were automatically collected in an acqueous solution containing a small number of Poros 50 R2 beads. ${ }^{13}$ These fractions were completely dried in a centrifugal vacuum concentrator and stored at $-20^{\circ} \mathrm{C}$ until further analysis by MALDI-MS. All MALDI-MS experiments were performed on a Bruker Reflex III MALDI-TOF mass spectrometer (Bruker Daltonik GmbH, Bremen, Germany). The peptides present in each reverse phaseHPLC fraction were first scanned in reflectron mode and peptides that were clearly enriched compared to the negative control sample were further on selected for MALDI-PSD analysis. The peptide fragmentation spectra obtained were automatically used for protein identification in a nonredundant protein database using the MASCOT-algorithm (http://www.matrixsciences.com).

\section{Isolation of U937 nuclei and measurement of DNA fragmentation}

Exponentially growing U937 cells $\left(200 \times 10^{6}\right.$ cells) were incubated for 30 min with $10 \mu \mathrm{M}$ cytochalasin B (Sigma, St. Louis, MO, USA) and collected by centrifugation for $5 \mathrm{~min}$ at $200 \times \mathrm{g}$. Cells were washed in cold PBS and rocked on ice for $20 \mathrm{~min}$ in NB buffer (10 mM HEPES$\mathrm{NaOH}$ pH 7.5, $10 \mathrm{mM} \mathrm{KCl}, 1.5 \mathrm{mM} \mathrm{MgCl}_{2}, 1 \mathrm{mM}$ DTT, $0.1 \mathrm{mM}$ PMSF). Cells were dounced 20 times and the homogenate was brought over a double volume of a sucrose cushion in NB complete buffer (NB+30\% sucrose) and spun down at $500 \times g$ for $6 \mathrm{~min}$ at $4^{\circ} \mathrm{C}$. The nuclear pellet was washed in CFS and nuclei were resuspended in CFS buffer. For studying DNA fragmentation, $10^{6}$ U937 nuclei were incubated in CFS buffer with a quarter of the mitochondrial supernatant for $2 \mathrm{~h}$ at $37^{\circ} \mathrm{C}$ in a total volume of $30 \mu \mathrm{l}$. Nuclei were lysed in TE buffer $(50 \mathrm{mM}$ Tris- $\mathrm{HCl}$ $\mathrm{pH} 8.0,10 \mathrm{mM}$ EDTA) with $0.5 \%$ SDS and $0.5 \mathrm{mg} / \mathrm{ml}$ proteinase $\mathrm{K}$ for $4 \mathrm{~h}$ at $37^{\circ} \mathrm{C}$. Proteins were extracted with TE-buffered phenol and DNA was precipitated with two volumes $\mathrm{EtOH}$ and $1 / 10$ volume of $4 \mathrm{M} \mathrm{NaCl}$ by overnight incubation at $-20^{\circ} \mathrm{C}$. The DNA pellet was resuspended in $0.1 \times \mathrm{TE}$ and loaded on a horizontal $1.8 \%$ agarose gel.

\section{Acknowledgements}

This work was supported in part by the Interuniversitaire Attractiepolen IV/ 26, the Fonds voor Wetenschappelijk Onderzoek-Vlaanderen (grant 
3G.0006.01), the Bijzonder Onderzoeksfonds, and the EC-RTD grant QLRT-1999-00739. M van Gurp is a fellow with the Vlaams Instituut voor de Bevordering van het Wetenschappelijk-technologisch Onderzoek in de Industrie. K Gevaert is a postdoctoral researcher with the Fonds voor Wetenschappelijk Onderzoek-Vlaanderen. The authors thank Dr. Guy Salvesen (The Burnham Institute, La Jolla, CA, USA) for providing recombinant CrmA, Ann Meeuws and Wilma Burm for expert technical assistance, Alex Raeymaeckers for recombinant TNF preparation and Myriam Goessens for animal care.

\section{References}

1. Liu X, Zou H, Slaughter $C$ and Wang X (1997) DFF, a heterodimeric protein that functions downstream of caspase-3 to trigger DNA fragmentation during apoptosis. Cell 89: 175-184

2. Enari M, Sakahira H, Yokoyama H, Okawa K, Iwamatsu A and Nagata S (1998)A caspase-activated DNase that degrades DNA during apoptosis, and its inhibitor ICAD. Nature 391: 43-50

3. Sakahira H, Enari M and Nagata $S$ (1998) Cleavage of CAD inhibitor in CAD activation and DNA degradation during apoptosis. Nature 391: 96 -99

4. Zhang J, Liu X, Scherer DC, van Kaer L, Wang X and Xu M (1998) Resistance to DNA fragmentation and chromatin condensation in mice lacking the DNA fragmentation factor 45. Proc. Natl. Acad. Sci. USA 95: 12480-12485

5. Mcllroy D, Tanaka M, Sakahira H, Fukuyama H, Suzuki M, Yamamura K, Ohsawa Y, Uchiyama $Y$ and Nagata S (2000) An auxiliary mode of apoptotic DNA fragmentation provided by phagocytes. Genes Dev. 14: $549-558$

6. Susin SA, Lorenzo HK, Zamzami N, Marzo I, Snow BE, Brothers GM, Mangion J, Jacotot E, Costantini P, Loeffler M, Larochette N, Goodlett DR, Aebersold R, Siderovski DP, Penninger JM and Kroemer G (1999) Molecular characterization of mitochondrial apoptosis-inducing factor. Nature 397: 441-446

7. Susin SA, Daugas E, Ravagnan L, Samejima K, Zamzami N, Loeffler M, Costantini P, Ferri KF, Irinopoulou T, Prevost MC, Brothers G, Mak TW, Penninger J, Earnshaw WC and Kroemer G (2000) Two Distinct Pathways Leading to Nuclear Apoptosis. J. Exp. Med. 192: 571-580

8. Sahara S, Aoto M, Eguchi $Y$, Imamoto N, Yoneda $Y$ and Tsujimoto $Y$ (1999) Acinus is a caspase-3-activated protein required for apoptotic chromatin condensation. Nature 401: 168-173

9. Robertson JD, Orrenius S and Zhivotovsky B (2000) Review: nuclear events in apoptosis. J. Struct. Biol. 129: 346-358

10. Los M, NeubuserD, CoyJF, Mozoluk M, Poustka A and Schulze-OsthoffK (2000) Functional characterization of DNase $\mathrm{X}$, a novel endonuclease expressed in muscle cells. Biochemistry 39: 7365-7373
11. Cote J and Ruiz-Carrillo A (1993) Primers for mitochondrial DNA replication generated by endonuclease $\mathrm{G}$. Science 261: 765-769

12. Rodriguez I, Matsuura K, Khatib K, Reed JC, Nagata S and Vassalli P (1996) A bcl-2 transgene expressed in hepatocytes protects mice from fulminant liver destruction but not from rapid death induced by anti-Fas antibody injection. J. Exp. Med. 183: 1031-1036

13. Gevaert K, Demol H, Sklyarova T, Vandekerckhove J and Houthaeve T (1998) A peptide concentration and purification method for protein characterization in the subpicomole range using matrix assisted laser desorption/ionization-postsource decay (MALDI-PSD) sequencing. Electrophoresis 19: 909-917

14. Parrish J, Li LY, Klotz K, Ledwich D, Wang $X$ and Xue D (2001) Mitochondrial endonuclease $G$ is important for apoptosis in $C$. elegans. Nature 412: 90-95

15. Li LY, Luo X and Wang X (2001) Endonuclease $G$ is an apoptotic DNase when released from mitochondria. Nature 412: 95-99

16. Kawane K, Fukuyama H, Adachi M, Sakahira H, Copeland NG, GilbertDJ, Jenkin NA and Nagata S (1999) Structure and promoter analysis of murine CAD and ICAD genes. Cell Death Differ. 6: 745-752

17. Li H, Zhu H, Xu CJ and Yuan J (1998) Cleavage of BID by caspase 8 mediates the mitochondrial damage in the Fas pathway of apoptosis. Cell 94: 491-501

18. LuoX, Budihardjo I, Zou H, Slaughter Cand Wang X (1998) Bid, a Bcl2 interacting protein, mediates cytochrome $c$ release from mitochondria in response to activation of cell surface death receptors. Cell 94: 481-490

19. Heibein JA, Goping IS, Barry M, Pinkoski MJ, Shore GC, Green DR and Bleackley RC (2000) Granzyme B-mediated cytochrome c release is regulated by the Bcl-2 family members bid and Bax. J. Exp. Med. 192: 1391-1402

20. Stoka V, Turk B, Schendel SL, Kim TH, Cirman T, Snipas SJ, Ellerby LM, Bredesen D, Freeze H, Abrahamson M, Bromme D, Krajewski S, Reed JC, Yin XM, Turk V and Salvesen GS (2001) Lysosomal protease pathways to apoptosis. Cleavage of bid, not pro-caspases, is the most likely route. J. Biol. Chem. 276: 3149-3157

21. Borner $C$ and Monney $L$ (1999) Apoptosis without caspases: an inefficient molecular guillotine? Cell Death Differ. 6: 497-507

22. Van de Craen M, Van Loo G, Declercq W, Schotte P, Van den brande I, Mandruzzato S, van der Bruggen P, Fiers W and Vandenabeele P (1998) Molecular cloning and identification of murine caspase-8. J. Mol. Biol. 284: 1017-1026

23. Schotte P, Van Criekinge W, Van de Craen M, Van Loo G, DesmedtM, Grooten J, Cornelissen M, De Ridder L, Vandekerckhove J, Fiers W, Vandenabeele P and Beyaert R (1998) Cathepsin B-mediated activation of the proinflammatory caspase-11. Biochem. Biophys. Res. Commun. 251: 379-387 